\title{
Brangus Cow-Calf Performance Under Two Stocking Levels on Chihuahuan Desert Rangeland
}

\author{
Milt Thomas, ${ }^{1}$ Jerry Hawkes, ${ }^{2}$ Godfrey Khumalo, ${ }^{3}$ and Jerry L. Holechek ${ }^{4}$
}

\begin{abstract}
Authors are ${ }^{1}$ Associate Professor, Department of Animal and Range Sciences, New Mexico State University, Las Cruces, NM 88003; ${ }^{2}$ Assistant Professor, Department of Agricultural Economics and Agricultural Business, New Mexico State Unversity, Las Cruces, NM 88003; ${ }^{3}$ PhD Student, Department of Animal and Range Sciences, New Mexico State University, Las Cruces, NM 88003; and ${ }^{4}$ Professor, Department of Animal and Range Sciences, New Mexico State University, Las Cruces, NM 88003.
\end{abstract}

\begin{abstract}
Cow-calf productivity on 2 lightly $(25 \%-30 \%$ use) and 2 conservatively grazed pastures ( $35 \%-40 \%$ use) were evaluated over a 5 -year-period (1997 to 2001) in the Chihuahuan Desert of south-central New Mexico. Spring calving Brangus cows were randomly assigned to study pastures in January of each year. Experimental pastures were similar in area (1 $098 \pm 69$ ha, mean \pm SE) with similar terrain and distance to water. Use of primary forage species averaged $28.8 \% \pm 4.3 \%$ in lightly stocked pastures and $41.8 \% \pm 4.4 \%$ on conservatively grazed pastures. Perennial grass standing crop (168.8 \pm 86 vs. $173.6 \pm 58.3$ $\left.\mathrm{kg} \cdot \mathrm{ha}^{-1}\right)$ and adjusted 205 -day calf weaning weights $(279.1 \pm 7.5$ vs. $270.7 \pm 7.8 \mathrm{~kg})$ did not differ among lightly and conservatively grazed pastures. Cow body condition scores in autumn, winter, and spring were similar among grazing levels as were autumn and winter body weights. However, cow body weights tended to be heavier $(P<0.10)$ in lightly grazed pastures relative to conservatively grazed pastures $(524 \mathrm{vs.} 502 \pm 9.7 \mathrm{~kg})$ in spring. Lightly grazed pastures yielded greater $(P<0.05) \mathrm{kg}$ of calf weaned $\cdot \mathrm{ha}^{-1}$ and calf crop percent than conservatively grazed pastures in 1998 due to destocking of conservatively grazed pastures during that year's drought. Conversely, pregnancy percent tended to be greater $(P<0.1)$ in conservatively relative to lightly grazed pastures $(92.6 \%$ vs. $87.7 \%)$; however, this advantage is explained by herd management as cows in the conservatively grazed pastures were removed during drought of 1998, avoiding exposure to the drought stress experienced by cows in the lightly grazed pastures. Nonetheless, pregnancy percents from both grazing treatments would be acceptable for most range beef production systems. Results suggest that consistently applying light grazing use of forage is a practical approach for Chihuahuan Desert cow-calf operations to avoid herd liquidation during short term drought.
\end{abstract}

\section{Resumen}

Durante 5 años (1997 al 2001) se evaluó la productividad de pares de vaca-becerro en 2 potreros apacentados ligeramente ( $25 \%-30 \%$ de uso) y 2 apacentados conservadoramente ( $35 \%-40 \%$ de uso) en el Desierto Chihuahuense de la parte sur-centro de New Mexico. En enero de cada año, vacas Brangus paridas en primavera se asignaron aleatoriamente a los potreros de estudio. Los potreros experimentales fueron similares en área (1 $098 \pm 69$ ha, media $\pm \mathrm{EE}$ ), terreno y distancia del agua. El uso de las principales especies forrajeras promedio $28.8 \pm 4.3 \%$ en los potreros apacentados ligeramente y $41.8 \pm 4.4 \%$ en los apacentados conservadoramente. La biomasa de zacates perennes $\left(168.8 \pm 86 \mathrm{vs.} 173.6 \pm 58.3 \mathrm{~kg} \cdot \mathrm{ha}{ }^{-1}\right)$ y los pesos de destete ajustados a 205 días $(279.1 \pm 7.5$ vs. $270.7 \pm 7.8 \mathrm{~kg})$ no difirieron entre los potreros apacentados ligera y conservadoramente. La calificación de la condición corporal en otoño, invierno y primavera fueron similares entre los niveles de apacentamiento, así como también lo fueron los pesos corporales en otoño e invierno. Sin embargo, en primavera, los pesos de las vacas tendieron a se mayores $(P<0.10)$ en los potreros con apacentamiento ligero que en los apacentados conservadoramente $(524$ vs. $502 \pm 9.7 \mathrm{~kg})$. En 1998, los potreros con apacentamiento ligero produjeron más $(P<0.05)$ kilogramos de becerro destetado por hectárea y un mayor porcentaje de becerros cosechados que los potreros apacentados conservadoramente, esto debido a la descarga de los potreros con apacentamiento conservador durante la sequía que se presentó en ese año. Contrariamente, el porcentaje de preñez tendió a ser mayor $(P<0.1)$ en los potreros apacentados conservadoramente que en los de uso ligero (92.6\% vs. $87.7 \%)$; pero, esta ventaja es explicada por el manejo del hato porque las vacas de los potreros con apacentamiento conservador fueron removidas durante la sequía de 1998 evitando el estrés experimentado por las vacas de los potreros con apacentamiento ligero. No obstante, los porcentajes de preñez de ambos tratamientos de apacentamiento serían aceptables para la mayoría de los sistemas de producción de ganado de carne. Los resultados sugieren que la aplicación consistente del uso ligero del forraje es un método práctico en los sistemas de producción de vaca-becerro del Desierto Chihuhuense para evitar la liquidación del hato durante periodos de sequía de corta duración.

Key Words: rangelands, grazing management, forage, drought, cattle productivity

Research supported by New Mexico Agricultural Experiment Station (Project 072944) and Range Improvement Task Force.

Correspondence: Jerry Holechek, Dept of Animal and Range Sciences, 2980 South Espina St, MSC 31, New Mexico State University, Las Cruces, NM 88003. Email: holechek@nmsu.edu

Manuscript received 1 February 2006; manuscript accepted 9 October 2006.

\section{INTRODUCTION}

Conservative grazing targeting $31 \%$ to $40 \%$ use of primary forage species appears to be a sound management practice for maintaining and improving ecological condition and forage 
production in the Chihuahuan Desert (Paulsen and Ares 1962; Holechek et al. 2003). Conservative grazing may offer other benefits to rangeland agricultural systems that include improved livestock productivity, lower variable costs, and similar or higher net financial returns per hectare compared to moderate $(41 \%-50 \%$ use of primary forage species) grazing use (Winder et al. 2000). Light grazing (20\%-30\% use of primary forage species) can further reduce management risk during drought and increase rate of range recovery following drought compared to moderate and conservative grazing (Klipple and Bement 1961; Valentine 1970; Holechek et al. 2003). Based on a review of stocking rate studies by Holechek et al. (1999), a limitation of light grazing compared to moderate grazing is reduced financial returns during periods of near average to above average precipitation. Light grazing is theoretically most advantageous in arid areas such as the Chihuahuan Desert characterized by periods of frequent and extended drought. In these areas, improved livestock productivity under light grazing may compensate to some extent for less efficient use of forage compared to conservative grazing. However, published reports of livestock productivity under light and conservative grazing are lacking. The objective of this study was to compare light and conservative grazing effects on cow-calf productivity on the Chihuahuan Desert Rangeland Research Center of south-central New Mexico.

\section{MATERIALS AND METHODS}

\section{Study Site}

The Chihuahuan Desert Rangeland Research Center (CDRRC) is located $37 \mathrm{~km}$ north of Las Cruces in south-central New Mexico and is in the southern portion of the Jornada del Muerto Plains between the San Andres Mountains to the east and the Rio Grande Valley to the west $\left(32.3^{\circ} \mathrm{N} ; 106^{\circ} \mathrm{W}\right)$. Elevation varies from 1188 to $1371 \mathrm{~m}$ with level to gently rolling hills. Soils of the CDRRC are mainly light sandy loams underlain by calcium carbonate hardpans at depths varying from a few $\mathrm{cm}$ to greater than $1 \mathrm{~m}$ (Valentine 1970; Joseph et al. 2003). They are classified as fine loamy, mixed thermic, typic haplargids and are in Simona-Cruces associations (SCS 1980).

Climatic conditions on the CDRRC are typical of the Chihuahuan Desert. The study site is arid and averages 200 frost-free days per year (Joseph et al. 2003). Wells and pipelines are the only permanent sources of water available for livestock on this research facility. In summer, temperatures are high with a mean maximum of $36^{\circ} \mathrm{C}$ during the month of June and a mean maximum of $13^{\circ} \mathrm{C}$ during January (Pieper and Herbel 1982). Winds are often strong in the spring of the year (Joseph et al. 2003). Rain gauges are well distributed throughout the CDRRC. Mean annual precipitation is $23 \pm 2.0 \mathrm{~cm}$, with $52 \%$ coming in the growing season of July to September. Average annual precipitation from 1997 through 2001 was $19.72 \pm 2.5$ $\mathrm{cm}$, which was $84 \%$ of the 60 -year average.

Primary grasses on the CDRRC are black grama (Bouteloua eriopoda (Torr.) Torr.), dropseeds (Sporobolus spp.), and threeawns (Aristida spp.). Honey mesquite (Prosopis glandulosa Torr.) and broom snakeweed (Gutierrezia sarothrae (Pursh) Britton \& Rusby) are the most commonly found shrubs.

\section{Pasture and Forage Use Description}

Four adjacent pastures with similar soils (sandy loams) and topography (flat) were delineated and fenced in 1991. Pasture 1 was 1267 ha, pasture 2 was 932 ha, pasture 3 was 1219 ha, and pasture 4 was 974 ha. Suitable grazing area for each pasture based on distance from water was calculated using procedures of Holechek (1988). Therefore, distance to water was not a concern for grazing distribution as stocking rates were based on area suitable for grazing.

Two treatments were randomly assigned to the 4 pastures in November of 1997. Pastures 1 and 3 were stocked to obtain $25 \%-30 \%$ forage use (light) and pastures 2 and 4 were stocked to obtain $35 \%-40 \%$ forage use (conservative). Stocking rates assigned to achieve these levels were based on the procedures of Holechek (1988). Pastures 1, 2, and 4 were in late-seral ecological condition, and pasture 3 was in mid-seral ecological condition based on the quantitative climax approach of Dyksterhuis (1949). Ecological condition scores for pastures $1,2,3$, and 4 at the beginning of the study in 1997 were $65 \%$, $60 \%, 46 \%$ and $63 \%$, respectively. At the end of the study in November of 2001, ecological conditions scores for pastures 1 , 2,3 , and 4 were $60 \%, 54 \%, 43 \%$, and $56 \%$, respectively.

Perennial grass standing crop data were collected in autumn of 1993 through 2001 at 10 evenly spaced key areas in each pasture (Joseph et al. 2003). Perennial grass standing crop and current year growth were determined by clipping twenty $0.5 \mathrm{~m}^{2}$ quadrats on each key area. Current year growth was separated from standing dead material. The reader is referred to Joseph et al. (2003) and Khumalo (2006) for information on total herbaceous standing crop, herbaceous standing crop relative composition, and percent cover of plant species on the study pastures. Grazing intensity on the 4 pastures was evaluated in 1997 through 2001 using procedures of Holechek and Galt (2000). Late June of each year was used to evaluate grazing intensity because it is the end of the forage cycle prior to new growth of perennial grasses which usually occurs in July. Percent use of the perennial grass standing crop was evaluated on 4 key areas within each pasture. Residual perennial grass biomass was determined by clipping twenty $0.5 \mathrm{~m}^{2}$ quadrats at each key area in late June. Annual percent forage use was calculated by dividing the late June perennial grass standing crop by the perennial grass standing crop in the previous autumn. This number was then subtracted from 1 and multiplied by 100 to obtain percent use. In drought years, black grama stubble heights were periodically checked during summer and autumn in all 4 pastures. If average stubble height fell below $7.6 \mathrm{~cm}$, the pasture would be destocked. A minimum stubble height of $7.6 \mathrm{~cm}$ has been recommended to avoid damage to black grama from excessive grazing (Paulsen and Ares 1962; Valentine 1970). Both low forage production and black grama heights near or below $7.6 \mathrm{~cm}$ justified the decision to destock the conservatively grazed pastures in 1998 and all pastures in autumn 2001.

\section{Experimental Animals}

Mature, pregnant, multiparous Brangus cows were randomly assigned by age and body condition score (BCS; scale $1=$ emaciated to $9=$ obese) to each pasture in January of each year. Each pasture was assigned a single-sire mated herd. Cow weights and BCSs were recorded each January, May, and 
Table 1. Mean \pm standard error of measures of autumn perennial grass standing crop $\left(\mathrm{kg} \cdot \mathrm{ha}^{-1}\right)$ from lightly and conservatively grazed pastures $\left(n=2\right.$ pastures $\cdot$ grazing treatment $^{-1}$ ) on the Chihuahuan Desert Rangeland Research Center.

\begin{tabular}{lcc}
\hline Year & Lightly grazed & Conservatively grazed \\
\hline 1997 & $202 \pm 104$ & $240 \pm 66$ \\
1998 & $184 \pm 126$ & $99 \pm 29$ \\
1999 & $245 \pm 140$ & $219 \pm 78$ \\
2000 & $193 \pm 85$ & $300 \pm 147$ \\
2001 & $66 \pm 32$ & $73 \pm 14$ \\
\hline
\end{tabular}

October. Reproductive performance (i.e., pregnancy and calf crop percentages) and calf weaning weights were determined each October.

Cattle were managed according to the procedures described by Thomas et al. (2002) and Obeidat et al. (2002). In brief, calving occurred in March through April, breeding occurred from 1 May through 1 August, and weaning occurred in midOctober. Birth and weaning weights were adjusted using guidelines of the Beef Improvement Federation (1996). These weights were also adjusted for sex of the calf (steer equivalence) as well as sire quality using expected progeny differences provided by the International Brangus Breeders Association. Protein supplementation ( 36\% CP and $72 \%$ TDN) was fed from 1 March to 2 May using $1 \mathrm{~kg}$ of a protein-based range cube $\cdot$ cow $^{-1} \cdot$ day $^{-1}$ (HiPro, Friona, TX). An energy block supplement from the same company $(18 \% \mathrm{CP}$ and $75 \% \mathrm{TDN})$ was fed from 2 May until the onset of summer rain and forage growth. Cows were palpated for pregnancy in autumn and nonpregnant cows were culled.

\section{Statistical Analyses}

Data were analyzed using the repeated measures procedures of PROC MIXED in SAS (SAS 2000; Littell et al. 1996). Pasture served as the experimental unit with stocking level, year, and the interaction of stocking level by year serving as fixed effects. Pasture nested within treatment served as the repeated term. When significance $(P<0.05)$ or tendencies $(P<0.10)$ occurred, means were separated using preplanned pair-wise comparisons generated with the least significant difference procedure involving PDIFF. Data are presented as mean \pm standard error.

\section{RESULTS AND DISCUSSION}

\section{Perennial Grass Production and Grazing Use}

From year 1997 through 2001, neither total annual (23.4 \pm $2.0 \mathrm{~cm}$, mean $\pm \mathrm{SE})$ nor growing season $(14.6 \pm 2.5 \mathrm{~cm} \mathrm{SE})$ precipitation differed $(P>0.10)$ among lightly and conservatively grazed pastures. The grazing treatment $\times$ year interaction was non-significant. Total annual and growing season precipitation tended to be lower $(P<0.10)$ in 1998 and 2001 than in 1997, 1999, and 2000. Based on growing season precipitation, both 1998 and 2001 were drought years $(75 \%$ or less of average precipitation; 16.2 and $12.8 \pm 2.0 \mathrm{~cm} \mathrm{SE}$, respectively).

Autumn perennial grass standing crop did not differ $(P>0.10)$ between light and conservative grazing levels (Table
Table 2. Mean \pm standard error of Brangus cow-calf production measures from lightly and conservatively grazed pastures on the Chihuahuan Desert Rangeland Research Center from 1997 through $2001\left(n=14.5 \pm 2.5 \mathrm{AU} \cdot\right.$ grazing treatment pasture $^{-1} \cdot$ year $\left.^{-1}\right)$.

\begin{tabular}{lcc}
\hline \multicolumn{1}{c}{ Trait } & Lightly grazed & Conservatively grazed \\
\hline Time of calving, Julian day & $83.5 \pm 1.1$ & $81.5 \pm 1.0$ \\
Calf adjusted birth wt, kg & $29.6 \pm 0.8$ & $28.5 \pm 0.9$ \\
Calf adjusted weaning wt, kg & $279.1 \pm 7.5$ & $270.7 \pm 7.8$ \\
Cow winter wt, kg & $586.1 \pm 1.8$ & $591.1 \pm 1.9$ \\
Cow winter BCS & $4.8 \pm 0.1$ & $4.8 \pm 0.1$ \\
Cow spring wt, kg & $524.5 \pm 9.5 \mathrm{a}$ & $502.4 \pm 9.7 \mathrm{~b}$ \\
Cow spring BCS & $5.1 \pm 0.1$ & $5.0 \pm 0.1$ \\
Cow autumn wt, kg & $528.6 \pm 25.0$ & $541.2 \pm 30.47$ \\
Cow autumn BCS & $5.1 \pm 0.3$ & $4.6 \pm 0.3$ \\
Pregnancy rate, \% & $87.7 \pm 1.9 \mathrm{a}$ & $92.6 \pm 2.0 \mathrm{~b}$ \\
\hline
\end{tabular}

a,b Means with different lowercase letters tend to differ $(P<0.10)$.

1). However, year tended to be a significant $(P<0.10)$ source of variation in this analysis, but there was no treatment $\times$ year interaction. Autumn perennial grass standing crop was lower $(P<0.10)$ in years 1998 and 2001 than in 1997, 1999, and 2000. Grazing use averaged $28.8 \pm 4.3 \%$ SE in lightly stocked pastures and $41.8 \pm 4.4 \%$ SE in conservatively stocked pastures. Specifically, in the years of 1997, 1998, 1999, 2000, and 2001 grazing use in lightly and conservatively grazed pastures was $14 \%$ and $30 \%, 36 \%$ and $46 \%, 39 \%$ and $56 \%, 25 \%$ and $37 \%$, and $30 \%$ and $40 \%$, respectively. Grazing impacts on perennial grass standing crop in September on these continuously grazed pastures were relatively minor because grass growth did not begin until July. With lightly and conservatively grazed pastures, only about $7.5 \%$ and $10.0 \%$ of current year growth of perennial grasses, respectively, is removed in July through September (data not shown). Daniel et al. (1993) and de Becerra et al. (1998) suggested that relatively low use of grasses during these months is related to the high palatability of annual forbs which may compose as much as $45 \%$ of the diet of cattle grazing the Chihuahuan Desert. Thus, the differential use of perennial grasses between the 2 treatments herein would be expected to express itself during winter and spring when the perennial grasses, particularly black grama, are most preferred by cattle. We acknowledge that collection of data on cattle diet botanical composition data would have allowed better interpretation of our results. We refer the reader to Khumalo (2006) for data on forb biomass on these study pastures. Because production, composition, and palatability of the annual forb crop varies greatly from year to year, we based stocking rates on perennial grass production as recommended by Paulsen and Ares (1962) and Holechek (1988).

\section{Cow-calf Production}

Calving dates, birth weights, and weaning weights were similar $(P>0.10)$ among lightly and conservatively grazed treatments (Table 2). In an earlier study on the CDRRC, Winder et al. (2000) found no difference in calf weaning weights among conservative and moderate grazing levels in a study involving young Barzona, Brangus, and Beefmaster cows. On the Fort Stanton Experimental Range in central New Mexico, Pieper 
et al. (1991) reported calf weaning weights were higher under moderate than heavy grazing (198 vs. $194 \mathrm{~kg}$ ) and light grazing proved to offer an advantage to gain in a heifer development program in saltbush dominated rangeland in Colorado (Derner and Hart 2005). Based on summaries by Pieper (1980) and Holechek et al. (1999), calf weaning weights generally decline when grazing intensities are increased from conservative to heavy levels. However, in the current study, differences in weaning weight were not detectable among lightly and conservatively grazed areas. Forage use at these levels are adequate to support similar calf weaning weights.

In 2001, calf weaning weights were reduced $\sim 10 \mathrm{~kg}$ $(P<0.10)$ relative to other years because of severe drought and poor forage growth. Previous studies on the CDRRC (Winder et al. 2000) and from other parts in New Mexico (Boykin et al. 1962; Pieper et al. 1991) have shown calf weaning weights were reduced in drought years and most importantly, in this study, $\mathrm{kg}$ of calf weaned $\cdot \mathrm{ha}^{-1}$ and calf crop percent could not be recorded during the drought of 1998 in the conservatively grazed pastures due to destocking (Fig. 1; grazing level $\times$ year; $P<0.05$ ). Destocking of the conservatively grazed pastures was based on procedures which avoid grazing below critical stubble height of primary grasses (Valentine 1970; Paulsen and Ares 1962). The lightly grazed pastures maintained $15 \pm 2 \mathrm{AU}$ in 1998. Number of animal units across years and treatment groups averaged $14.5 \pm 2.5$.

Body weight and BCS are typically used as indicators of reproductive potential of beef cows (Houghton et al. 1990; Lalman et al. 1997). Herein, measures of cow-herd productivity differed $(P<0.05)$ among years, but BCS were similar $(P>0.10)$ across grazing levels as were winter and autumn body weights (Table 2). However, there was a tendency $(P<0.10)$ for cow spring weights to be heavier in lightly grazed pastures versus conservatively grazed pastures. This was most likely a consequence of greater quality and/or quantity of forage in the lightly grazed pastures and the potential for more nutrient availability during winter and early spring grazing. These types of interactions have been reported in other grazing studies of cow-calf units (Sims 1993; Coleman et al. 2001).

Pregnancy rates tended $(P<0.10)$ to be greater in conservatively stocked pasture relative to lightly grazed pastures (Table 2); however, these pregnancy rates would both be desirable for most range cow-calf beef systems (Adams et al. 1994; Winder et al. 2000). The relatively high pregnancy rates in both treatment groups were probably a result of nutritional supplements and the low grazing intensities in this study. Herd management probably also influenced these results as cows in conservatively grazed pastures probably experienced less drought stress as they were removed from the drought conditions of desert grazing in 1998 while cows in lightly grazed pastures were sustained.

Drought can be frequent and of extended time periods in the Chihuahuan Desert. From the results herein, we conclude that consistently applying light grazing use of forage over years is a practical approach for Chihuahuan Desert Brangus cow-calf operations to avoid herd liquidation during short term drought.
Za Lightly Grazed Conservatively Grazed
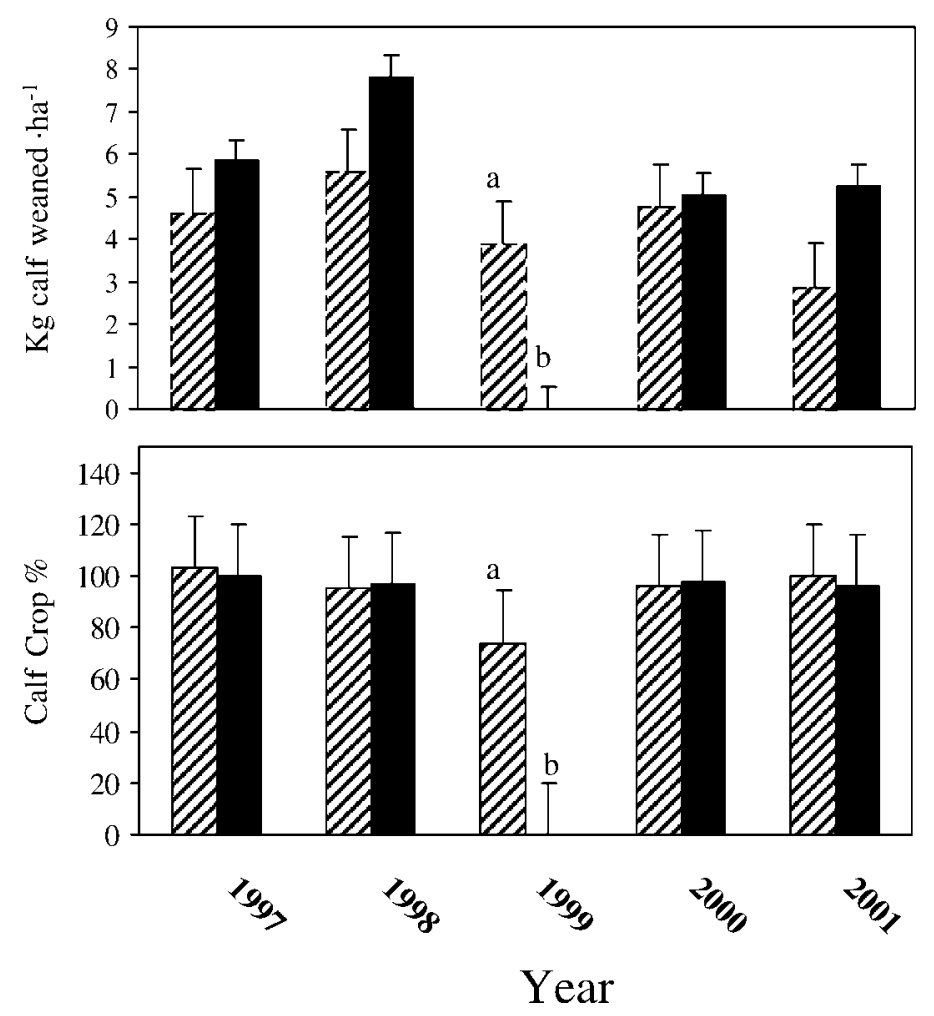

Figure 1. $\mathrm{Kg}$ of calf weaned $\cdot \mathrm{ha}^{-1}$ (top panel) and calf crop (\%; bottom panel) in lightly and conservatively grazed pastures on the Chihuahuan Desert Rangeland Research Center. Means within a year with different letters are significantly different $(P<0.05)$.

\section{MANAGEMENT IMPLICATIONS}

Conservative grazing has been the recommended grazing intensity for Chihuahuan Desert Rangelands based on various studies of vegetation, livestock productivity, and financial returns. However, during periods of extended drought such as in 1944 to 1956 and more recently 1994 to present, ranchers using conservative grazing were forced to liquidate their herds due to lack of forage. Light grazing ( $25 \%$ use) of forage production reduces stocking level about one-third compared to conservative grazing ( $35 \%$ use). Light grazing presents lower risk for destocking and more management flexibility during a short-term drought such as lack of rainfall during one season of forage growth. When forage growth resumes post-drought, cattle adapted to a specific environment such as the Chihuahuan Desert can be difficult to locate for purchase and restocking. Also drought cycles are not coordinated with the US cattle price cycle. These two realities exacerbate management and financial risk of conservative grazing levels and those of greater use levels in the Chihuahuan Desert.

\section{LITERATURE CITED}

Adams, D. C., R. T. Clark, S. A. Coady, J. B. Lamb, and M. K. Neilsen. 1994. Extended grazing systems for improved economic returns from Nebraska sandhills cow/ calf operations. Journal of Range Management 47:258-263. 
[BIF] Beef Improvement Federation. 1996. Guidelines for uniform beef improvement programs. 7th edition, Ed. C. Bailey, Writing and Business Support, Reno, NV p 12-13.

Boykin, C. C., J. R. Gray, and D. P. Caton. 1962. Ranch production adjustments to drought in eastern New Mexico. New Mexico Agricultural Experiment Station Bulletin 470:41 p.

Coleman, S. W., W. A. Phillips, J. D. Volesky, and D. Buchanan. 2001. A comparison of native tallgrass prairie and plains bluestem forage systems for cow-calf production in the southern Great Plains. Journal of Animal Science 79: 1697-1705.

Daniel, A., J. L. Holechek, R. Valdez, A. Tembo, L. Saiwana, M. Fusco, and M. Cardenas. 1993. Range condition influences on Chihuahuan Desert cattle and jackrabbit diets. Journal of Range Management 46:296-301.

de Becerra, R., J. Winder, J. L. Holechek, and M. Cardenas. 1998. Diets of three cattle breeds on Chihuahuan Desert rangeland. Journal of Range Management $51: 270-275$

Derner, J. D., and R. H. HaRt. 2005. Heifer performance under two stocking rates on fourwing saltbush-dominated rangeland. Rangeland Ecology and Management 58:489-494.

DykSTeRHuis, E. J. 1949. Condition and management of rangeland based on quantitative ecology. Journal of Range Management 2:104-115.

HOLECHEK, J. L. 1988. An approach for setting the stocking rate. Rangelands 10:10-14.

HolecheK, J. L., And D. Galt. 2000. Grazing intensity guidelines. Rangelands 22: $11-14$.

Holechek, J. L., H. Gomez, F. Molinar, and D. Galt. 1999. Grazing studies: what we've learned. Rangelands 20:12-16.

Holechek, J. L., D. Galt, J. Joseph, J. Navarro, G. Khumalo, F. Molinar, and M. THomAs. 2003. Moderate and light cattle grazing effects on Chihuahuan Desert rangelands. Journal of Range Management 56:133-139.

Houghton, P. L., R. P. Lemenager, L. A. Hostman, K. S. Hendrix, and G. E. Moss. 1990. Effects of body condition, pre and postpartum energy level and early weaning on reproductive performance of beef cows and preweaning calf gain. Journal of Animal Science 68:1438-1446.

Joseph, J., M. Collins, J. Holechek, R. Valdez, and R. Steiner. 2003. Conservative and moderate grazing effects on Chihuahuan Desert wildlife sightings. Western North American Naturalist 63:43-49.

KHumALO, G. 2006. Long-term trends and productivity under conservative and light grazing on Chihuahuan Desert rangelands: Applications to Swaziland beef cattle production [dissertation]. Las Cruces, NM: New Mexico State University. $19 \mathrm{p}$.
Klipple, G. E., and R. E. Bement. 1961. Light grazing: is it feasible as a range improvement practice? Journal of Range Management 14:57-62.

Lalman, D. L., D. H. Keisler, J. E. Williams, E. J. Schollejgerdes, and D. M. Mallet. 1997. Influence of postpartum weight and condition change on duration of anestrus by undernourished suckled beef heifers. Journal of Animal Science 75:2003-2008.

Littell, R. C., G. A. Milliken, W. W. Stroup, and R. D. Wolfinger. 1996. SAS system for mixed models. Cary, NC: SAS Institute, Inc. p 87-134.

Obeidat, B. S., M. G. Thomas, D. M. Hallford, D. H. Keisler, M. K. Petersen, W. D. Bryant, M. D. Garcia, L. Narro, and R. Lopez. 2002. Metabolic characteristics of multiparous Angus and Brahman cows grazing in the Chihuahuan Desert. Journal of Animal Science 80:2223-2233.

Paulsen, H. A. JR., and E. N. Ares. 1962. Grazing values and management of black grama and tobosa grasslands and associated shrub ranges of the Southwest. US Department of Agriculture Forest Service Technical Bulletin 1270. $56 \mathrm{p}$.

PiePeR, R. D. 1980. Impacts of grazing systems on livestock: Proceedings of Grazing Management Systems for Southwest Rangelands Symposium; 7-9 December 1980; Albuquerque, NM. New Mexico State University. 245 p.

Pieper, R. D., AND C. H. Herbel. 1982. Herbage dynamics and primary productivity of a desert grassland ecosystem. New Mexico Agricultural Experiment Station Bulletin $695.43 \mathrm{p}$.

Pieper, R. D., E. E. Parker, G. B. Donart, J. D. Wallace, and J. D. Wright. 1991. Cattle and vegetation in response to four-pasture rotation and continuous grazing. New Mexico Agricultural Experiment Station Bulletin 756. 23 p.

SAS. 2000. User's Guide: Statistics. Cary, NC: Institute Inc. 152 p.

[SCS] Soll Conservation Service. 1980. Soil survey of Doña Ana County, New Mexico. Las Cruces, NM: Soil Conservation Service, USDA. 188 p.

Sims, P. L. 1993. Cow weights and reproduction on native rangeland and native rangeland-complementary forage systems. Journal of Animal Science 71:1704-1711.

Thomas, M. G., R. M. Enns, D. M. Hallford, D. H. Keisler, B. S. Obeidat, C. D. Morrison, J. A. Hernandez, W. D. Bryant, R. Flores, R. Lopez, and L. Narro. 2002. Relationships of metabolic hormones and serum glucose to growth and reproductive development in performance-tested Angus, Brangus, and Brahman bulls. Journal of Animal Science 80:757-767.

Valentine, K. A. 1970. Influence of grazing intensity on improvement of deteriorated black grama range. New Mexico Agricultural Experiment Station Bulletin 553. $21 \mathrm{p}$.

Winder, J., C. C. Bailey, M. G. Thomas, and J. L. Holechek. 2000. Effect of breed and stocking rate on Chihuahuan Desert cattle production. Journal of Range Management 53:32-38. 